\title{
Investigation of Mechanical Properties of Shale Rock in Qassim Region, Saudi Arabia
}

\author{
Mohammad A. Irfan \\ Department of Mechanical Engineering \\ University of Engineering and Technology \\ Peshawar, Pakistan \\ mairfan@uetpeshawar.edu.pk
}

\author{
Fahad A. Almufadi \\ College of Engineering \\ Qassim University \\ Saudi Arabia \\ almufadi@qec.edu.sa
}

\begin{abstract}
An investigation into the mechanical properties of shale rock from Qassim Province, Saudi Arabia is presented in this paper. Uniaxial compression test, Schmidt hammer test and porosity estimation were carried out. Regarding the compression test, it was found that the strength ranged from $1.98 \mathrm{MPa}$ to $8 \mathrm{MPa}$ and the strain ranged from $0.53 \%$ to $2.5 \%$. Regarding the Schmidt Hammer test, it was found that the rebound values ranged from 22.4 to 25 . The measurements of volumetric porosity indicated that the porosity in the shale rock ranged between $19.12 \%$ and $24.31 \%$. All the values determined in this project match well with the published values of other studies about shale rock.
\end{abstract}

Keywords-shale rock; mechanical properties; Qassim province; Saudi Arabia

\section{INTRODUCTION}

Shale oil and gas production from organic rich shale formations is a growing area of technical interest in oil and gas exploration. Long horizontal wells with hydraulic fracturing are required to bring economic production from shale gas reservoirs. Since crack propagation in hydraulic fracturing occurs under high strain rates, it is important to understand the fracture behavior of shale rock and its mechanical properties. The properties of shale rock that are needed in order to be able to design the hydraulic fracturing systems include: compressive strength, hardness, porosity, modulus of elasticity, Poisson's ratio, fracture toughness and permeability. Rocks in general can be classified as: igneous rocks, sedimentary rocks, and metamorphic rocks. Sedimentary rocks are made when products of weathering are subjected to transportation by water, winds or deposition and subsequently are compacted or consolidated. Some examples are sandstone, shale, conglomerate, breccias, limestone, and coal. Minerals forming sedimentary rocks are kaolinite, illite, smectite, hematite, rutile, corundum and so on. Shale is basically a sedimentary rock with fine grains, composed of mud which is a mixture of flakes of clay minerals and small particles of other minerals, mostly quartz and calcite.

Numerous experimental and theoretical investigations have demonstrated how mechanical properties in sedimentary rocks are affected by porosity [1], clay content [2], overburden stress and pore fluid [3]. Further understanding needs to be developed on how these parameters control rock strength. The aim of this paper is to test the mechanical properties of Saudi shale rock from Qassim province, under static loading. Rock samples were taken from shale formations in Qassim region, Saudi Arabia. Uniaxial compression test, Schmidt hammer test and porosity estimation were carried out.

\section{LITERATURE REVIEW}

\section{A. Uniaxial Compression Test of Shale Rock}

Weak rocks are defined by their ultimate compressive strength (UCS) in the range of 0.25 to $25 \mathrm{MPa}$ [4]. A good strength limit for weak rocks may be $20 \mathrm{MPa}$ because rocks weaker than this behave differently when sheared [5]. Sedimentary rocks such as sandstone, siltstone, shale, claystone or mudstone, clay-shale fall under the classification of weak rocks $[6,7]$. The prime factor affecting the strength of weak rocks is porosity. Commonly, high porosity gives low strength and vice versa. Table I summarizes some available strength data for sandstone and shale. It can be seen that higher porosity leads to weak compressive strength.

TABLE I. COMPRESSIVE STRENGTH AS RELATED TO POROSITY

\begin{tabular}{|c|c|c|c|}
\hline Reference & Location & Porosity \% & Compressive strength (MPa) \\
\hline$[5]$ & Kidderminster (UK) & $\sim 31$ & 2 to 3 \\
\hline$[8]$ & $\begin{array}{c}\text { Bringelly Shale, } \\
\text { Australia }\end{array}$ & $7 \%$ to $14 \%$ & 2.4 to 49 \\
\hline
\end{tabular}

\section{B. Schmidt Hammer Test}

Schmidt Hammer test is commonly used for testing different rocks and has a strong correlation with UCS through numerous empirical equations. Schmidt hammer rebound (R) values were directly used in the analysis and were not converted to UCS, since there is no standard conversion designated for shale. Table II shows the range of $\mathrm{R}$ values for Sevier and Rome shale [9].

TABLE II. SHALE ROCK COMPRESSIVE STRENGTH ESTIMATION [9]

\begin{tabular}{|c|c|}
\hline Type of Shale & Schmidt Hammer Rebound (R) \\
\hline Sevier Shale & 30 \\
\hline Rome Shale & 38 \\
\hline
\end{tabular}




\section{Porosity}

Porosity is defined as the fraction of a rock occupied by pores. It is a static property which can be measured by various methods in the absence of fluid flow. To find effective porosity fluid flow is required to ascertain whether the pores are interconnected. Table III presents some data on average porosity. Nearly all the measurements were made at room temperature and pressure of 1 atmosphere [10].

TABLE III. AVERAGE POROSITY FOR SHALE ROCK [10]

\begin{tabular}{|c|c|}
\hline Title & Average Porosity $(\phi)$ \\
\hline Shale (Near Ponca City, Oklahoma) & $42.5 \%$ \\
\hline Shale (Eastern Venezuela) & $33.5 \%$ \\
\hline Shale (Los Manueles field, Venezuela) & $20.0 \%$ \\
\hline Shale (Ponca City and Garber areas, Oklahoma) & $17.0 \%$ \\
\hline Weston Shale (Bonner Springs, Kansas) & $15.8 \%$ \\
\hline Chanute Shale (Independence, Kansas) & $14.9 \%$ \\
\hline
\end{tabular}

\section{MATERIALS AND METHODS}

Shale rock samples were collected from a local cement quarry in Qassim, Saudi Arabia. A total of 40 samples were obtained for initial testing.

\section{A. Specimens Preparation}

The cutting of samples was completed in the Civil Engineering lab at Qassim University, using its sample preparation machine. It took five days to complete prepare the specimens to finally obtain only 20 proper samples out of 40 . Figure 1 shows the shale samples before they were cut into cubical shapes. The specimens were cut as $50 \mathrm{~mm} \times 50 \mathrm{~mm} \times 50 \mathrm{~mm}$ cubes as per ASTM C 109/C $109 \mathrm{M}$. There may be some errors in the dimensions due to the difficulty in precision cutting of soft rocks. Also, there is a maximum expected dimension error of $\pm 2 \mathrm{~mm}$.

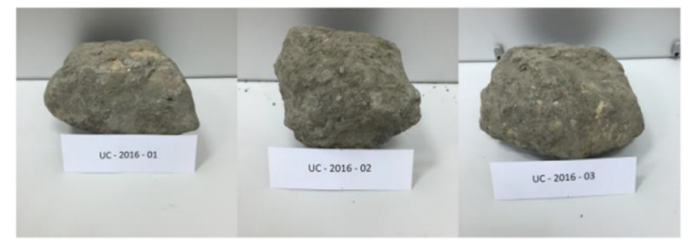

Fig. 1. Samples before cutting

\section{RESULTS AND DISCUSSION}

\section{A. Uniaxial Compression Test}

The laboratory uniaxial compressive strength is the standard strength parameter of intact rock material. An MTS universal tensile testing machine used with capacity of $25 \mathrm{kN}$ was used. Table IV shows the results of the compression test. The average strength of the 4 samples used is $2.5 \mathrm{MPa}$. Table IV also shows the strain values of the 4 samples. The maximum is $2.5 \%$ for sample 3 and the minimum is $0.91 \%$ for sample 1, while the average is $1.46 \%$. It is important to compare the results with previous ones, to observe and discuss their differences. Table $\mathrm{V}$ represents the uniaxial compressive strength of shale rock and its associated porosity, from [5], in comparison with Qassim shale results investigated in this paper. The average porosity of Qassim shale was $22.54 \%$. The average UCS of Qassim shale was $2.5 \mathrm{MPa}$ which is well within the range of internationally published values as shown in Table V.

TABLE IV. TENSILE TEST SUMMARY

\begin{tabular}{|c|c|c|}
\hline Sample No. & Strength (MPa) & Strain (\%) \\
\hline 1 & 2.13 & 0.91 \\
\hline 2 & 2.38 & 1.26 \\
\hline 3 & 3.53 & 2.5 \\
\hline 4 & 1.98 & 1.16 \\
\hline
\end{tabular}

TABLE V. RESULTS COMPARISON

\begin{tabular}{|c|c|c|c|}
\hline Reference & Location & Porosity \% & $\begin{array}{c}\text { Compressive strength } \\
\text { (MPa) }\end{array}$ \\
\hline$[5]$ & Kidderminster (UK) & $\sim 31$ & 2 to 3 \\
\hline$[8]$ & $\begin{array}{c}\text { Bringelly Shale, } \\
\text { Australia }\end{array}$ & $7 \%$ to $14 \%$ & 2.4 to 49 \\
\hline $\begin{array}{c}\text { Current } \\
\text { study }\end{array}$ & $\begin{array}{c}\text { Qassim, } \\
\text { Saudi Arabia }\end{array}$ & $19 \%$ to $24 \%$ & 1.98 to 3.53 \\
\hline
\end{tabular}

\section{B. Schmidt Hammer Test}

Three samples were tested by Schmidt hammer. The dimensions of the samples were $50 \mathrm{~mm} \times 50 \mathrm{~mm} \times 50 \mathrm{~mm}$. An Ntype Schmidt hammer with an impact energy of $2.2 \mathrm{~N}$.m was used to measure rock hardness. Table VI shows pictures of the three samples before and after the test. It also shows the rebound and strength values obtained. The maximum rebound value was in sample 2, where sample 3 had the minimum value. Note that the empirical relation used to estimate the compressive strength in [11] could not be valid for the specimens used in this test.

TABLE VI. SCHMIDT HAMMER TEST RESULTS

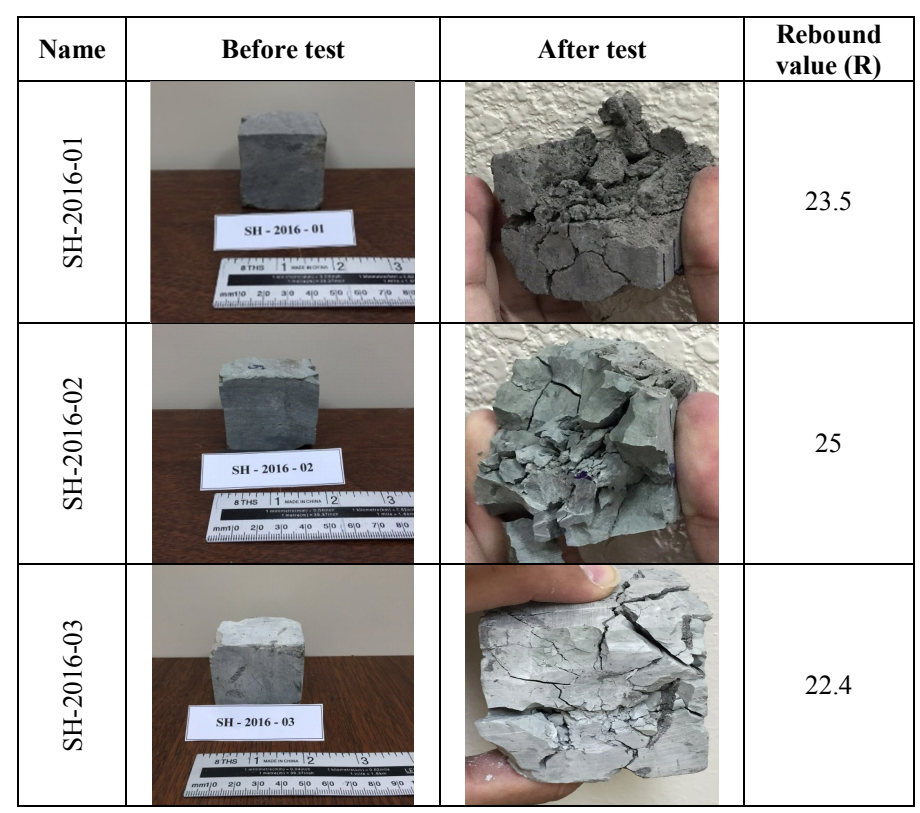

Tables VII-VIII show the results of this study in comparison with previously published results [9]. 
TABLE VII. RESULTS COMPARISON WITH SEVIER SHALE [9]

\begin{tabular}{|c|c|c|}
\hline $\begin{array}{c}\text { Sample Number } \\
\text { of current study }\end{array}$ & $\begin{array}{c}\text { Absolute Difference of } \\
\text { Schmidt Hammer } \\
\text { Rebound Value (R) }\end{array}$ & $\begin{array}{c}\text { Difference of Schmidt } \\
\text { Hammer Rebound } \\
\text { Value (\%) }\end{array}$ \\
\hline SH-2016-01 & 6.5 & 21 \\
\hline SH-2016-02 & 5 & 16 \\
\hline SH-2016-03 & 7.6 & 25 \\
\hline
\end{tabular}

TABLE VIII. RESULTS COMPARISON WITH ROME SHALE [9]

\begin{tabular}{|c|c|c|}
\hline $\begin{array}{c}\text { Sample Number } \\
\text { of current study }\end{array}$ & $\begin{array}{c}\text { Absolute Difference of } \\
\text { Schmidt Hammer } \\
\text { Rebound Value (R) }\end{array}$ & $\begin{array}{c}\text { Difference of Schmidt } \\
\text { Hammer Rebound } \\
\text { Value (\%) }\end{array}$ \\
\hline SH-2016-01 & 14.5 & 38 \\
\hline SH-2016-02 & 13 & 34 \\
\hline SH-2016-03 & 15.6 & 41 \\
\hline
\end{tabular}

\section{Determination of Porosity}

Mathematically, porosity can be defined by (1):

$$
\text { Porosity }=\phi=\frac{V_{p}}{V_{b}}=\frac{V_{b}-V_{m}}{V_{b}}
$$

where $\phi$ : porosity (\%), $V_{b}$ : bulk volume $\left(\mathrm{cm}^{3}\right), V_{p}$ : pore volume $\left(\mathrm{cm}^{3}\right)$, and $V_{m}$ : matrix volume (grain volume) $\left(\mathrm{cm}^{3}\right) . V_{b}$ of the sample was measured by the volumetric displacement method. $V_{m}$ was measured by crushing the sample to grain size and immersing it in a container filled with water. Substituting the results in (1) we have the results shown in Table IX:

TABLE IX. SUMMARY OF RESULTS

\begin{tabular}{|c|c|}
\hline Sample No. & Porosity $(\phi)$ \\
\hline 1 & $19.12 \%$ \\
\hline 2 & $24.15 \%$ \\
\hline 3 & $24.31 \%$ \\
\hline
\end{tabular}

Table $\mathrm{X}$ shows the porosity results comparison of shale rock in current study and in [10]. It can be seen that porosity measured values lie within the range of other published values.

TABLE X. COMPARISON WITH [10]

\begin{tabular}{|c|c|c|c|}
\hline Title & Average $\phi[10]$ & Qassim average $\phi$ & $\begin{array}{c}\text { Percent } \\
\text { difference }\end{array}$ \\
\hline $\begin{array}{c}\text { Shale (Near Ponca } \\
\text { City, Oklahoma) }\end{array}$ & $42.5 \%$ & & $+20.03 \%$ \\
\hline $\begin{array}{c}\text { Shale (Eastern } \\
\text { Venezuela) }\end{array}$ & $33.5 \%$ & $+10.03 \%$ \\
\hline $\begin{array}{c}\text { Shales (Los } \\
\text { Manueles field, } \\
\text { Venezuela) }\end{array}$ & $20 \%$ & \multirow{2}{*}{$22.53 \%$} & $-2.53 \%$ \\
\hline $\begin{array}{c}\text { Shale (Ponca City } \\
\text { and Garber areas, } \\
\text { Oklahoma.) }\end{array}$ & $17 \%$ & $-5.53 \%$ \\
\hline $\begin{array}{c}\text { Weston Shale } \\
\text { (Bonner Springs, } \\
\text { Kansas) }\end{array}$ & $15.8 \%$ & & $-6.73 \%$ \\
\hline $\begin{array}{c}\text { Chanute Shale } \\
\text { (Independence, } \\
\text { Kansas) }\end{array}$ & $14.9 \%$ & $-7.63 \%$ \\
\hline
\end{tabular}

\section{CONCLUSION AND FUTURE WORK}

Uniaxial compressive strength was tested for 4 different samples, ranged from $1.98 \mathrm{MPa}$ to $5 \mathrm{MPa}$ and with an average of $2.5 \mathrm{MPa}$, while the strain ranged between $0.91 \%$ and $2.5 \%$ and had an average of $1.46 \%$. The Schmidt hammer test results found that the rebound values ranged from 22.4 to 25 . Displacement method was used to determine the Qassim shale rock porosity, the results were $19.12 \%, 24.15 \%$ and $24.31 \%$ and the average porosity was $22.53 \%$. The samples for this study were taken from a cement quarry. In future, samples can be derived from the drilling core, because that would give more meaningful results for shale gas exploration. Another suggestion is to calculate shale rock's modulus of elasticity and Poisson's ratio. Schmidt hammer can be done with a lighter Ltype Schmidt hammer, which has impact energy 0.735N.m. In addition, impact tests can also be conducted.

\section{ACKNOWLEDGEMENT}

Authors would like to thank undergraduate students Suhail A. Aswailem, Abdurehman S. Alquba and Ahmed M. Alhasan for conducting the experiments as a part of their senior project.

\section{REFERENCES}

[1] M. R. Wyllie, A. R. Gregory, G. H. F. Gardner, “An experimental investigation of factors affecting elastic wave velocities in porous media”, Geophysics, Vol. 23, pp. 459-493, 1957

[2] D. Han, A. Nur, D. Morgan, "Effect of porosity and clay content on wave velocity in sandstones", Geophysics, Vol. 51, pp. 2093-2017, 1986

[3] M. S. King, "Static and dynamic elastic properties of rocks from the Canadian Shield", International Journal of Rock Mechanics and Mining Sciences \& Geomechanics Abstracts, Vol. 20, No. 5, pp. 237-241, 1983

[4] R. Ulusay, The ISRM Suggested Methods for Rock Characterization, Testing and Monitoring: 2007-2014, Springer, Switzerland, 2015

[5] L. Dobereiner, M. H. de Freitas, "Geotechnical properties of weak sandstones”, Geotechnique, Vol. 36, pp. 79-94, 1986

[6] J. C. Jaeger, N. G. W. Cook, R.W. Zimmerman, Fundamentals of Rock Mechanics, Blackwell Publishing, 2007

[7] S. Klein, "An approach to the classification of weak rock for tunnel projects", 2001 Rapid Excavation and Tunneling Conference, San Diego, USA, June 11-13, 2001

[8] W. Ezzat, Engineering Performance of Bringelly Shale, PhD Thesis, University of Sydney, 2005

[9] A. Nandi, C. M. Liutkus, M. J. Whitelaw, "Geotechnical characterization of Sevier and Rome shale, East Tennessee", 43rd U.S. Rock Mechanics Symposium and 4th U.S. -Canada Rock Mechanics Symposium, Asheville, USA, June 28-July 1, 2009

[10] G. E. Manger, Porosity and Bulk Density of Sedimentary Rocks, US Government Printing Office, 1963

[11] F. I. Shalabi, E. J. Cording, O. H. Al-Hattamleh, "Estimation of rock engineering properties using hardness tests", Engineering Geology, Vol. 90, No. 3-4, pp. $138-147,2007$

\section{AUTHORS PROFILE}

Mohammad A. Irfan did his $\mathrm{PhD}$ in Mechanical Engineering from Case Western Reserve University, Cleveland, OH, USA in 1998. Following his $\mathrm{PhD}$ he worked for 2 years in the US industry. His work was related to the design of industrial burners. He has been awarded with the Fulbright postdoctoral fellowship in 2008. During his post doc he conducted research on reducing porosity in aluminum die castings. He joined Qassim University, in 2010. Currently he is working as a Professor of Mechanical Engineering at the University of Engineering and Technology, Peshawar, Pakistan.

Fahad A. Almufadi did his PhD from Ohio University, USA in 2004. He joined Qassim University, Saudi Arabia in 2009 where he was in charge of different academic and administration positions starting with mechanical engineering department head, then vice dean and currently he is the dean of the Engineering College. 